\title{
Bot en kwaliteit: samen sterker?!
}

Citation for published version (APA):

van den Bergh, J. P. W. (2015). Bot en kwaliteit: samen sterker?! Maastricht University. https://doi.org/10.26481/spe.20151002jb

Document status and date:

Published: 02/10/2015

DOI:

10.26481/spe.20151002jb

Document Version:

Publisher's PDF, also known as Version of record

\section{Please check the document version of this publication:}

- A submitted manuscript is the version of the article upon submission and before peer-review. There can be important differences between the submitted version and the official published version of record.

People interested in the research are advised to contact the author for the final version of the publication, or visit the DOI to the publisher's website.

- The final author version and the galley proof are versions of the publication after peer review.

- The final published version features the final layout of the paper including the volume, issue and page numbers.

Link to publication

\footnotetext{
General rights rights.

- You may freely distribute the URL identifying the publication in the public portal. please follow below link for the End User Agreement:

www.umlib.nl/taverne-license

Take down policy

If you believe that this document breaches copyright please contact us at:

repository@maastrichtuniversity.nl

providing details and we will investigate your claim.
}

Copyright and moral rights for the publications made accessible in the public portal are retained by the authors and/or other copyright owners and it is a condition of accessing publications that users recognise and abide by the legal requirements associated with these

- Users may download and print one copy of any publication from the public portal for the purpose of private study or research.

- You may not further distribute the material or use it for any profit-making activity or commercial gain

If the publication is distributed under the terms of Article $25 \mathrm{fa}$ of the Dutch Copyright Act, indicated by the "Taverne" license above, 
Prof. dr. Joop P. van den Bergh

Faculty of Health, Medicine and Life Sciences

\section{Bot en kwaliteit: samen sterker?!}




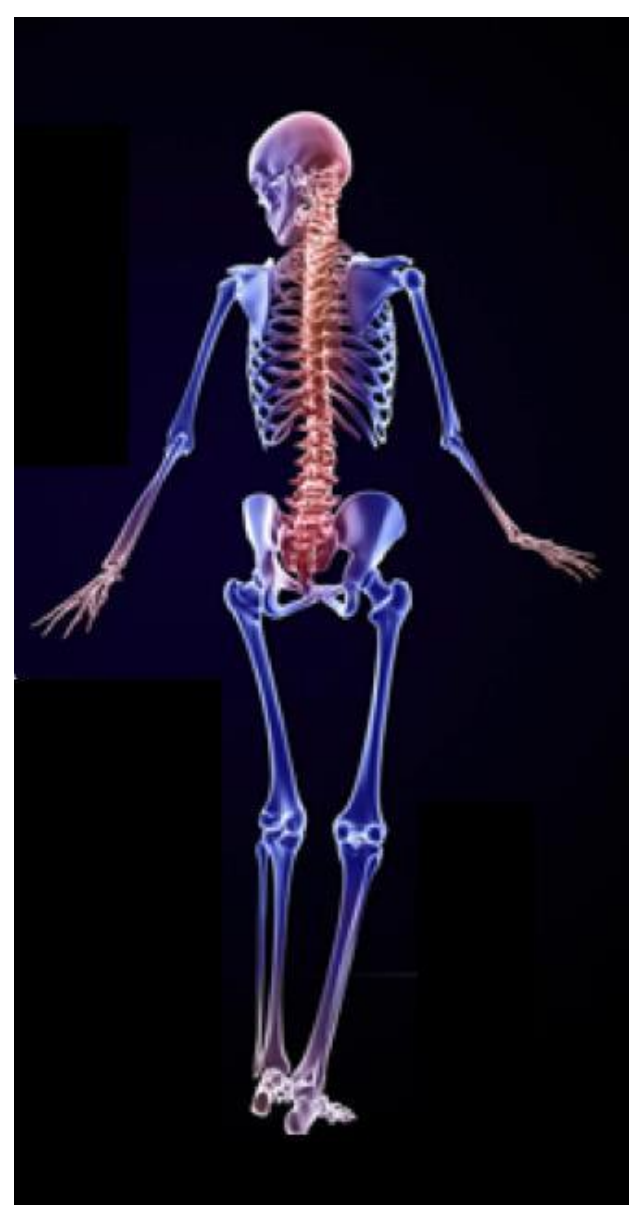

\section{Bot en kwaliteit: samen sterker?!}

Inaugurale rede Prof. Dr. Joop P. van den Bergh 2 oktober 2015 
Geachte pro-rector, bestuurders, collegae, familieleden, vrienden en toehoorders,

In deze lezing zal ik trachten u wegwijs te maken in de achtergronden van ons onderzoek en het klinisch denken in het kader van botkwaliteit en metabole botaandoeningen.

Allereerst enige vitleg over de anatomie van bot en de botstofwisseling.

\section{Botals orgaan}

Bot is een zeer dynamisch multifunctioneel orgaan dat per jaar voor 5 tot $10 \%$ wordt vernieuwd. Het biedt ondersteuning aan het gehele lichaam en vormt de hefbomen waarmee beweging door spieren mogelijk is. Daarnaast biedt het bescherming aan kwetsbare organen in de borstholte, het bekken en de schedel, huisvest bot de cellen verantwoordelijk voor de bloedaanmaak en tot slot is het een zeer belangrijk reservoir voor mineralen zoals calcium en fosfaat. De activiteit van de cellen die verantwoordelijk zijn voor botaanmaak (osteoblasten) en botafbraak (osteoclasten) bepalen de balans van het bot en worden gedirigeerd door de osteocyten. De osteocyten hebben een signaalfunctie en in geval van mechanische belasting of beschadigingen in het bot sturen zij de osteoblasten en osteoclasten aan om het botweefsel aan te passen aan de omstandigheden of te repareren.

\section{Botstofwisseling}

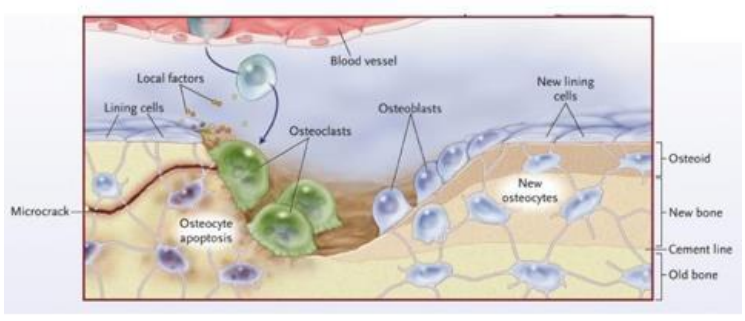

Het positieve daarvan is dat het skelet zich kan aanpassen tijdens de groeifase, bij toename van lichamelijke inspanning, botbreuken kunnen hersteld worden en materiaal dat in het bot wordt aangebracht bij operaties wordt ingebouwd en blijft vast zitten. De balans van de botstofwisseling kan echter ook nadelig verstoord worden, zoals bijvoorbeeld bij vrouwen tijdens en na de overgang waarbij door het wegvallen van het hormoon oestrogeen de botafbraak toeneemt.
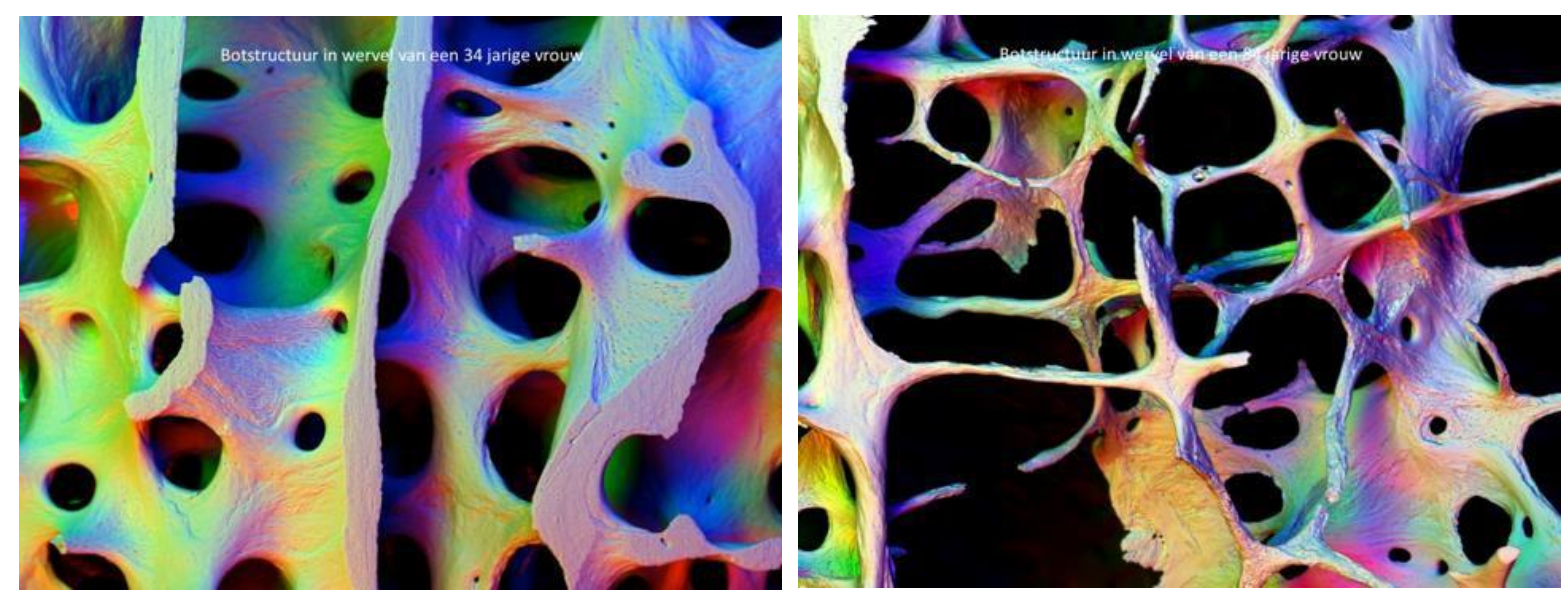

Hoe onderzoeken we bot in de dagelijkse praktijk

Wanneer we in de dagelijkse praktijk willen onderzoeken wat de consequenties zijn in het bot gebruiken we in de praktijk sinds halverwege de jaren negentig de botdichtheidsmeting met Dual Energy $X$-ray

Absorptiometry (DEXA) als standaardonderzoek. DEXA apparatuur maakt gebruik van een röntgentechniek waarmee de botdichtheid in de wervelkolom en de heup gemeten kan worden en de vitslag van deze meting 
wordt ingedeeld in 3 categorieën: normale of verlaagde botdichtheid of osteoporose. De diagnose osteoporose wordt gesteld op basis van een afgenomen botmassa in vergelijking met de piekbotmassa van een jong volwassene (voor vrouwen en mannen wordt een aparte referentiewaarde gebruikt). Alhoewel bruikbaar in de dagelijkse praktijk heeft de DEXA techniek beperkingen omdat het een meting is van de botdichtheid in het 2-dimensionale vlak, die echter geen informatie geeft over de 3-dimensionale structuur en meer in het bijzonder de kwaliteit van het bot en de botsterkte.

Dual Energy X-ray Absorptiometry (DEXA)
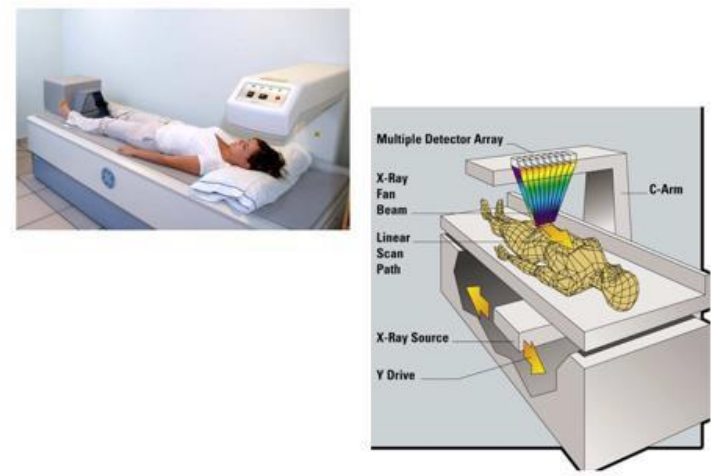

\section{Botkwaliteit}

De term botkwaliteit is niet eenvoudig te omschrijven. De internationaal meest gebruikte definitie is afgeleid van de ISO standaard definities voor kwaliteit en luidt: "The totality of features and characteristics that influence a bone's ability to resist fracture". Daarmee wordt botkwaliteit rechtstreeks gekoppeld aan botsterkte en (het risico op) fracturen maar op basis van het onderzoek dat we in MUMC zijn we van mening dat botkwaliteit in een breder perspectief gezien moet worden.

Meer in detail kan botkwaliteit worden omschreven door de structuur en de materiaaleigenschappen van het botweefsel, die de mechanische eigenschappen bepalen. De structuur en materiaaleigenschappen kunnen worden onderverdeeld van macroscopisch tot nanoscopisch en moleculair niveau. Zo kan de structuur van het botweefsel omschreven worden door de geometrie van een geheel botstuk, de micro-architectuur (zoals de corticale en de trabeculaire microstructuur), de oriëntatie van het materiaal en de mate van porositeit. De weefseleigenschappen worden bepaald door de mate en kwaliteit van het collageen, de kristalstructuur, de mate van mineralisatie en de opgetreden micro-schade.

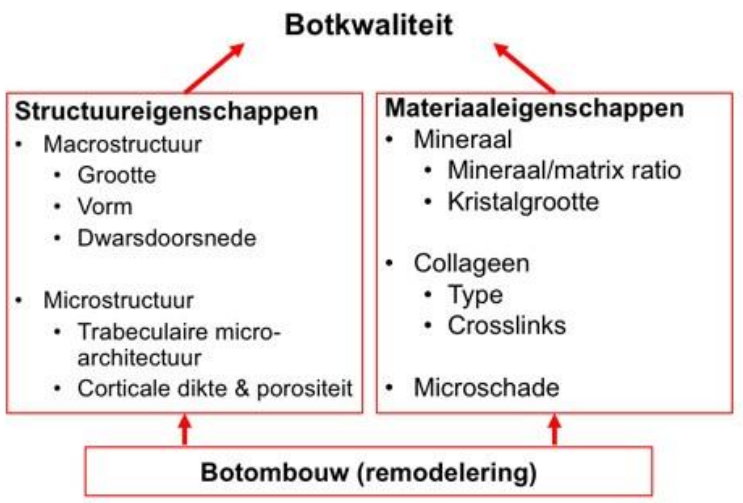

Het is momenteel in de klinische praktijk niet mogelijk om alle genoemde eigenschappen van bot in-vivo te meten. Wel kunnen we tegenwoordig met name de structuureigenschappen goed bestuderen met behulp van DEXA, CT en hoge resolutie perifere CT apparatuur. Met name de inzet van de HR-pOCT (hoge resolutie perifere kwantitatieve $(T)$ techniek is sinds de aanschaf in 2010 één van de speerpunten in het Maastrichtse onderzoek. Met deze scanner kan een scan in de distale radius (onderarm) en distale tibia (onderbeen) gemaakt worden met hoge resolutie zodat de individuele botbalkjes en andere eigenschappen in detail bestudeerd kunnen worden en de botsterkte in-vivo berekend kan worden. MUMC+ heeft in 2014 in 
samenwerking met VieCuri MC Noord-Limburg inmiddels een tweede HRpQCT scanner geïnstalleerd en is daarmee het enige centrum in de Benelux die deze techniek ter beschikking heeft.

\section{High resolution imaging in-vivo}

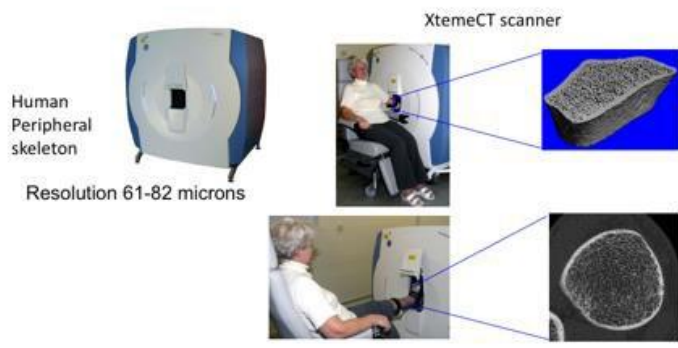

HR-pQCT beeldvorming / eindige elementen analyse (FEA)
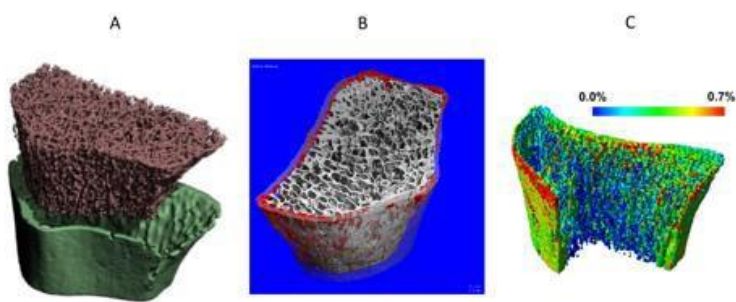

A) gescheiden corticaal en trabeculair compartiment (B) de corticale porositeit in rood gemarkeerd

C) visualisatie van de strain distributie (procentuele lengteverandering onder belasting) in de distale radius

\section{Metabole botaandoeningen}

De term metabole botaandoeningen is een verzamelnaam voor aandoeningen of stoornissen die botafbraak induceren en dus nadelig zijn voor het skelet doordat de botstructuur en de materiaaleigenschappen worden aangetast met als gevolg een afname van de botkwaliteit en botsterkte. Het gevolg daarvan is dat het risico op een botbreuk toeneemt.

Bij een aantal endocriene aandoeningen wordt door de hormonale afwijking de balans in botaanmaak en botafbraak verstoort waardoor veelal de botafbraak toeneemt, osteoporose (botontkalking) ontstaat waardoor het risico op botbreuken toeneemt. Het is dan ook niet toevallig dat ik tijdens mijn opleiding tot endocrinoloog geïnteresseerd raakte in deze materie. Duidelijk is dat niet alleen endocriene aandoeningen een nadelige invloed hebben op het skelet, maar dat dit ook geldt voor gastro-intestinale, reumatologische, hematologische aandoeningen, longziekten, maar ook meer algemene zaken zoals een tekort aan vitamine $D$, calcium, roken, alcoholgebruik) alsmede vele medicamenten.

Mijn leeropdracht 'botkwaliteit en metabole botaandoeningen' heeft als doelstelling de interactie tussen fractuurrisico, metabole botaandoeningen en botkwaliteit met een belangrijk accent op integratie van kennis en onderzoek van klinische specialismen die zich bezig houden met de diverse metabole botaandoeningen nader te bestuderen. Dit wordt uitgewerkt in diverse onderzoekslijnen.

\section{COPD en wervelfracturen}

Uit recent onderzoek en met name de proefschriften van Lidwien Graat-Verboom en Lisette van der VeldenRomme blijkt dat de prevalentie van osteoporose bij patiënten met COPD (Chronische Obstructieve Long Ziekte) hoog is, namelijk bij ongeveer $1 / 3$ van alle patiënten. Dat is veel hoger dan bij gezonde personen en vergelijkbaar met de prevalentie van osteoporose bij patiënten na een recente fractuur. $\mathrm{Bij} 1 / 3$ van de COPD patiënten is sprake van minimaal één wervelinzakking. Chronische ontsteking en gebruik van prednisolon zijn in het algemeen belangrijke oorzaken voor skeletverslechtering. Deze bevindingen tonen aan dat bij patiënten met COPD de botkwaliteit duidelijk is verminderd en dat structurele analyse van het skelet zinvol is in deze patiëntengroep. In de dagelijkse praktijk is dit echter nog niet vanzelfsprekend. Zowel osteoporose als wervelinzakkingen worden vaak niet gediagnosticeerd bij deze patiëntengroep. Recent onderzoek in kleine studies wijst op een relatie tussen het aantal wervelinzakkingen en de daarmee gepaard gaande deformiteit van de thorax (kyphosering) en een afname van het longvolume. Daarnaast heeft recent onderzoek in MUMC aangetoond dat de (afname van) botstructuur en botsterkte gerelateerd is aan de diffusiecapaciteit (diffusie, de mate waarin de long zuurstof kan opnemen). Deze interessante bevindingen worden momenteel verder onderzocht in samenwerking met de vakgroepen longziekten van MUMC+, Ciro Horn, het Catharina ziekenhuis Eindhoven en de Technische Universiteit Eindhoven. De nadruk daarbij ligt op de relatie tussen botkwaliteit, osteoporose, longfunctie en het ontstaan van (wervel)fracturen bij patiënten met COPD. De onderzoeksgroep ontwikkelt momenteel een (semi)geautomatiseerde methode waarbij uit de standaard CTscans van de longen, verkregen uit de internationale ECLIPSE (Evaluation of COPD Longitudinally to Identify Predictive Surrogate Endpoints) study het aantal wervelfracturen, de botmassa en botsterkte en de eventuele 
deformatie / kyphosering van de wervelkolom zal worden berekend. Deze unieke studie met follow-up gedurende 3 jaren maakt het mogelijk om botkwaliteitsaspecten te bestuderen in relatie tot relevante klinisch uitkomsten zoals longfunctieverlies, fractuurrisico, co-morbiditeiten en mortaliteit.

\section{COPD en wervelkolom}

- $1 / 3$ osteoporose

- $1 / 3$ wervelinzakking(en)

- Beeldvorming longen én bot
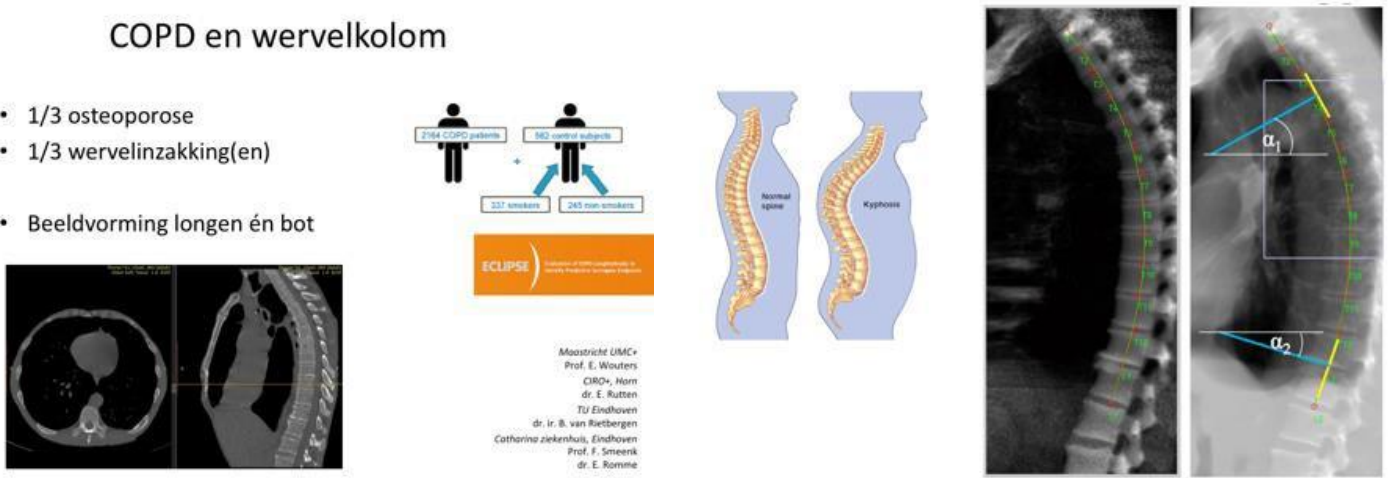


\section{Diabetes Mellitus type 2 en het skelet}

Als internist-endocrinoloog houdt ik mij dagelijks bezig met de zorg voor patiënten met Diabetes Mellitus en het opmerkelijke bij met name DM type 2 is dat patiënten een verhoogd fractuurrisico hebben, terwijl de meeste onderzoeken laten zien dat de botdichtheid normaal of zelfs wat hoger is in vergelijking met gezonde personen. De oorzaak zou dus gelegen kunnen zijn bij een verhoogd valrisico en / of een verminderde botkwaliteit. Het valrisico kan bij deze patiënten met name verhoogd zijn door diabetische complicaties zoals retinopathie en neuropathie in combinatie met valrisico verhogende medicatie (vaak polyfarmacie). Temeer omdat de DEXA meting geen aanknopingspunt levert, immers de botdichtheid is normaal of zelfs verhoogd, is de evaluatie van de botstructuur en botsterkte interessant om nader te onderzoeken. Toen in de loop van 2009, onder andere door een schenking van Stichting de Weijerhorst, de mogelijkheid bestond om een HRPQCT scanner aan te schaffen was een van de doelstellingen om in de diabetespraktijk van de vakgroep Interne Geneeskunde in VieCuri MC een onderzoek te starten. In diezelfde periode raakte ik in gesprek met Prof. Dr. A. Schols en bleek het mogelijk om het toen nog niet ontsproten klinisch onderzoek, hoofdzakelijk gebaseerd op inzet van deze nieuwe scanner, onder te gaan brengen binnen NUTRIM. Tegelijkertijd was de Maastricht Studie, onder leiding van Prof. Dr. C. Stehouwer, in de opstartfase en kon het plan uitgewerkt worden om de scanner te plaatsen in het gebouw van de Maastricht Studie waardoor fantastische mogelijkheden voor diabetes gerelateerd botonderzoek ontstonden. Inmiddels draait De Maastricht Studie (een uniek onderzoek onder de Zuid-Limburgse bevolking naar het voorkomen, de oorzaken en de behandeling van type 2 diabetes, hart- en vaatziekten en andere chronische aandoeningen) op volle toeren en ongeveer 1500 personen met en zonder DM zijn al onderzocht met de HR-pOCT scanner. Een van onze doelstellingen is om een predictie model te ontwerpen met implementatie van genetische en metabole parameters alsmede klinische risicofactoren, botmineraaldichtheid (DEXA) en botkwaliteit (HR-pQCT) voor het optreden van fracturen en mortaliteit voor zowel de controlepopulatie als het cohort met Diabetes Mellitus type 2. Deze gegevens zullen worden geïntegreerd met gegevens betreffende spierfunctie, beweging en valincidenten uit de De Maastricht Studie. Aanvullend zal de relatie tussen botkwaliteit en cardiovasculair risico nader bestudeerd gaan worden.

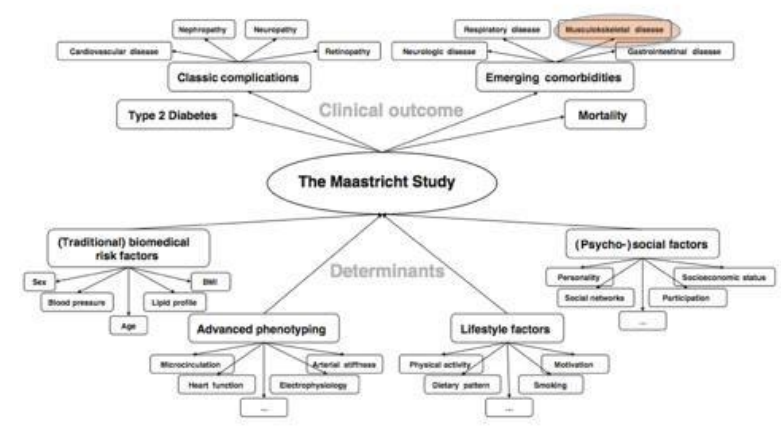

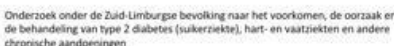

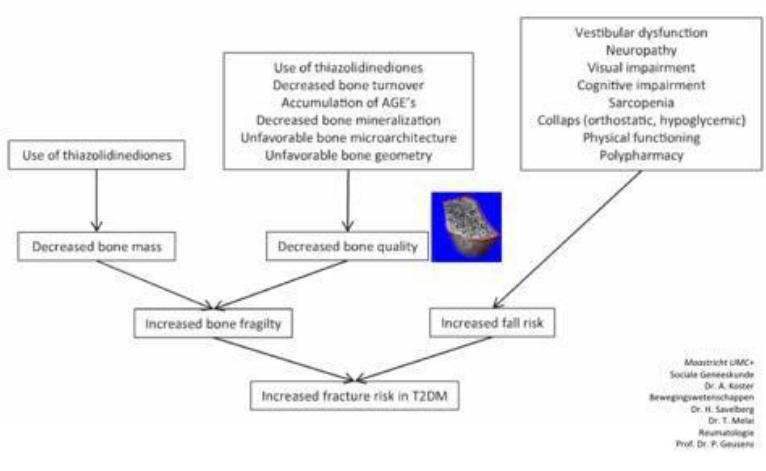

Twee andere hoofdlijnen van mijn onderzoek hebben betrekking op andere aspecten van botkwaliteit. Dit betreft de bestudering van botkwaliteit tijdens fractuurgenezing van distale radiusfracturen en van botkwaliteit in de handgewrichten bij reumatoïde artritis. De interesse komt voort vit eerder onderzoek dat ik in UMC Radboud heb kunnen verrichten. Toen ik eind jaren negentig tijdens mij opleiding tot endocrinoloog mijn ambitie voor promotie onderzoek kenbaar maakte aan Prof. Dr. Hermus, opleider endocrinologie en later ook mijn promotor kwam hij met het voorstel om "iets te gaan doen" met een nieuw apparaat dat gebruik maakte van ultrageluid om het hielbot -de calcaneus- te meten. Eenmaal aan de slag met deze nieuw aangeschafte apparatuur rees de vraag wat precies in het bot gemeten werd. Immers, destijds was slechts enkele jaren daarvoor de DEXA apparatuur geïntroduceerd in de medische praktijk en dat was toen, en overigens nu nog steeds, de "gouden standaard" meting voor de diagnostiek van osteoporose.

Aangezien het ultrageluid apparaat geen gebruik maakte van röntgenstralen ontstond de vraag of met deze verschillende technieken verschillende aspecten van het bot gemeten werden en zo ja, welke. Naar aanleiding van deze vraag werd contact gelegd met de afdeling Biomechanica van Prof. Dr. Huiskes, in het Radboud UMC, waar toen Dr. B van Rietbergen (TU Eindhoven) en Prof. Dr. H. van Lenthe (Universiteit Leuven, België) als jonge onderzoekers werkten. Op deze afdeling leerde ik werken met een micro-CT scanner waarmee we in 
staat waren om op basis van de computerbeelden een berekening van de botsterkte te maken en de vergelijkende studie tussen botmetingen met DEXA en ultrageluidsapparatuur toonde aan dat de botsterkte beter kon worden ingeschat met de ultrageluidsmeting. De micro-CT metingen konden destijds alleen ex-vivo gedaan worden maar tegenwoordig, en dan maak ik een sprong in de tijd, kunnen we in-vivo de HR-pQCT meting toepassen.

\section{Bestudering van botkwaliteit tijdens fractuurgenezing van distale radiusfracturen}

Fractuurgenezing is één van de ultieme modellen om botkwaliteit te kunnen bestuderen. Immers in het bot moet in korte tijd schade opgeruimd en hersteld worden wat een maximale inspanning van het botmetabolisme vraagt. Met de HR-pQCT scanner wordt standaard in de distale radius een meting verricht, dus leek het mij interessant en ook voor de hand liggend het genezingsproces van distale radiusfracturen te bestuderen. In het voortraject van de aanschaf van de scanner werd de samenwerking met Dr. B van Rietbergen van de TU Eindhoven, expert in computeranalyses van bot, opgestart en werd het plan voor de bestudering van de fractuurheling verder uitgewerkt. Vervolgens werd met de afdelingen orthopedie (Prof. Dr. L. Van Rhijn, Dr. P. Willems en Dr. C. Arts) en heelkunde (Prof. Dr. Brink en Dr. M. Poeze) de fractuurheling werkgroep in 2011 vormgegeven. Inmiddels is een tweetal promovendi (Joost de Jong en Frans Heyer) werkzaam op dit project en waren we vorig jaar als eerste en vooralsnog enige groep in staat de heling van distale radiusfracturen op basis van HR-pOCT beelden te kwantificeren in structuurparameters en botsterkte. Momenteel wordt een tweetal onderzoeken in MUMC+ en Viecuri MC met interventie met Calcium en Vitamine D uitgevoerd om te beoordelen of de fractuurgenezing daarmee sneller of beter verloopt. In de toekomst lijkt het mogelijk de invloeden van medicatie en biomaterialen op fractuurgenezing met dit model te kunnen bestuderen.

HR-pQCT / $\mu$ FEA tijdens genezing van een polsfractuur

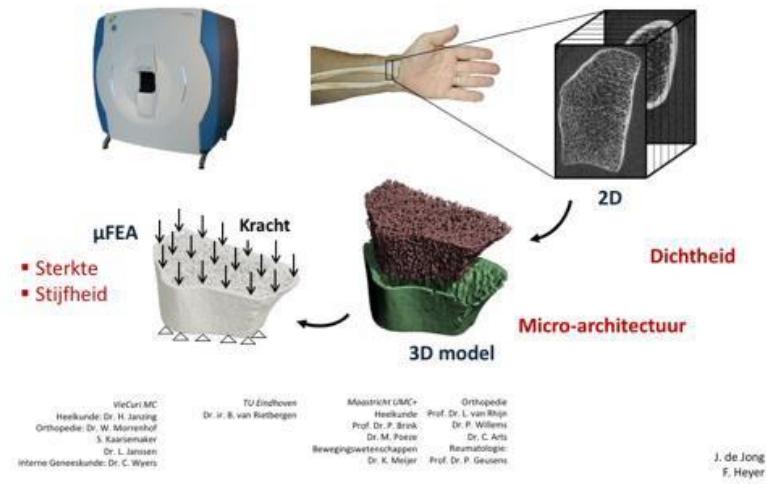

Novel application of HR-pQCT: healing of distal radius fracture

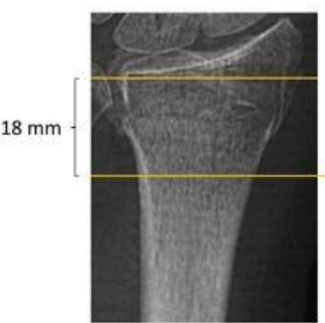

X-ray

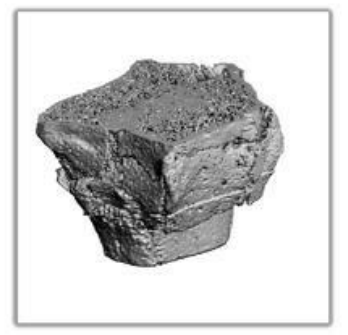

HR-pQCT

\section{4. $\quad$ Bestudering van botkwaliteit in de handgewrichten bij reumatoïde artritis}

Reumatoïde artritis (RA) is het prototype van voorbeeld waarin auto-immuniteit het bot aantast, ter hoogte van de gewrichten maar ook elders verspreid over het skelet. In een groot bevolkingsonderzoek is aangetoond dat patiënten met RA een verhoogd risico hebben op fracturen. Ter hoogte van de gewrichten ontstaan boterosies die tot misvormingen van de gewrichten kunnen leiden. Er is hier in Maastricht vroeger met succes veel onderzoek uitgevoerd naar het belang van boterosies vastgesteld op röntgenfoto's van de handen en voeten. De beeldvorming evolueert met de toepassing van de hoge resolutie CT scan, met name bij het bestuderen van de kleine handgewrichten. In samenwerking met Dr. Ir. B van Rietbergen ontwikkelt promovendus Ir. Michiel Peters een automatische methode om onderbrekingen in de cortex van het bot van de kleine vingergewrichtjes vast te stellen. We ontdekken varianten in het skelet die niet eerder konden worden waargenomen in-vivo en dankzij de intensieve samenwerking tussen de afdelingen Reumatolgie (Prof. Dr. P Geusens en Dr. A. Van Tubergen) en radiologie (Prof. Dr. J Wildberger, Dr. R Weijers en D. Loeffen) komen we stapsgewijs verder met het ontrafelen van de betekenis en mogelijke toepassingen van deze beeldvorming. Promovendus A. Scharmga evalueert de toepassing van HR-pQCT naast het gebruik van echografie, röntgenbeelden en MRI in een MUMC cohort met RA. 

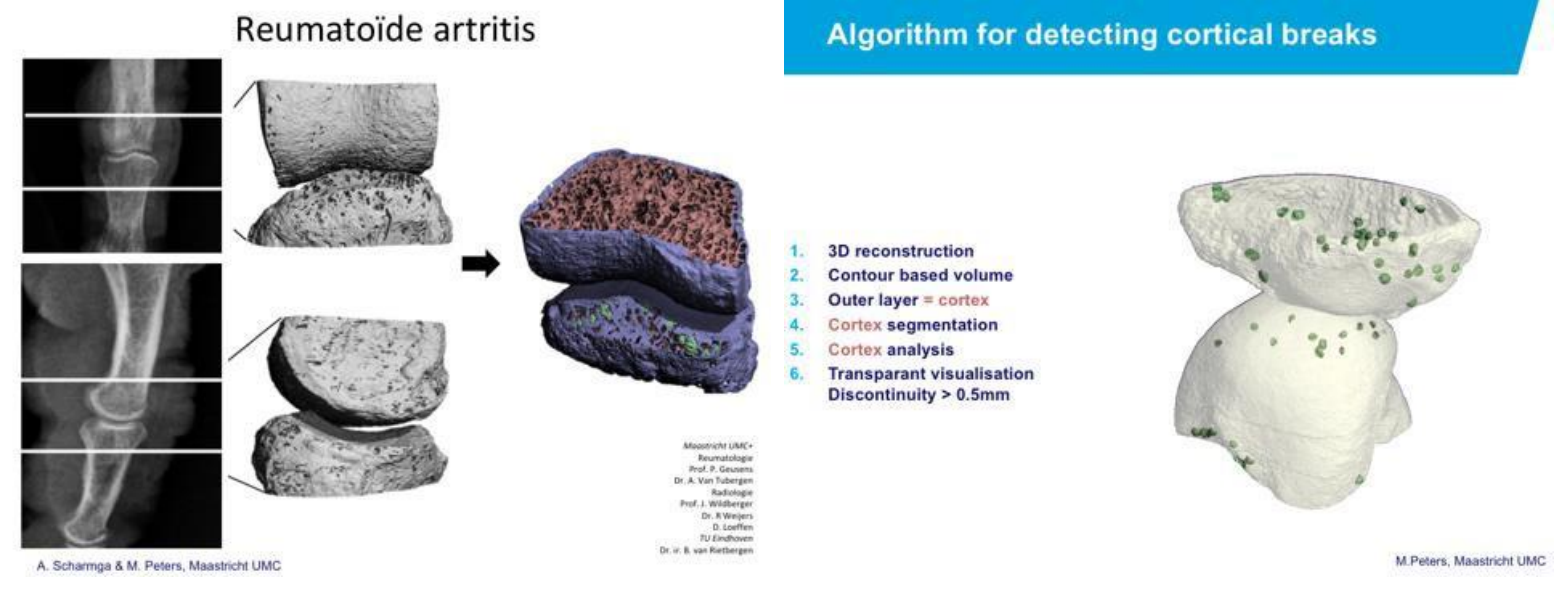

\section{Bestudering van botkwaliteit en metabole botaandoeningen in relatie tot klinische vitkomsten, in het bijzonder fracturen en mortaliteit}

Hoe groot is het probleem: hoeveel mensen krijgen een botbreuk en wat zijn de consequenties?

In samenwerking met het onderzoeksinstituut IMTA in Rotterdam heb ik de in Nederlandse ziekenhuizen geregistreerde en gefactureerde DBC codes gedurende het jaar 2010 in kaart gebracht en op basis van demografische trends is een voorspelling gemaakt van de aantallen fracturen en daarmee gepaard gaande kosten in de komende 20 jaar. Hieruit blijkt dat in 2010 in Nederland 120.000 fracturen werden behandeld in de leeftijdsgroep 50 jaar en ouder, 85.000 bij vrouwen en 35.000 bij mannen. Tot voor kort werd aangenomen dat dit aantal 80.000 betrof (CBO 2011 en NHG 2012 richtlijn - gegevens afkomstig van het RIVM (2004)). De incidentie van fracturen zal op basis van onze voorspellingen tot 2030 met $40 \%$ toenemen, de directe aan de fractuurbehandeling gekoppelde kosten (nu ongeveer 600 miljoen euro per jaar) zullen met ongeveer $50 \%$ toenemen! De indirecte kosten, die minstens even aanzienlijk zijn blijkens recent onderzoek door Prof. Dr. W. Lems in VUmc, zijn daarin niet meegerekend.

De afdelingen huisartsgeneeskunde, heelkunde, orthopedie, interne geneeskunde, reumatologie, nucleaire geneeskunde en radiologie van het MUMC+ en later ook VieCuri MC doen sinds ruim 10 jaar systematisch onderzoek gedaan naar de ernst en prevalentie van metabole botaandoeningen, het optreden van nieuwe fracturen en mortaliteit bij patiënten ouder dan 50 jaar, die zich presenteren met een fractuur op de spoedeisende hulp (SEH).

In MUMC heeft het onderzoek op de fractuurpoli onder supervisie van Prof. Dr. P Geusens de laatste jaren geleid tot een aantal nieuwe inzichten die zijn verwerkt in een drietal proefschriften. Bij DEXA onderzoek blijkt dat $40 \%$ van deze groep osteoporose heeft, binnen 5 jaar krijgt bijna 1 op 5 patiënten een nieuwe fractuur en 1 op 3 komt binnen 5 jaar te overlijden.

Tineke van Geel (HAG) kon aantonen dat 50-plussers met een fractuur met name kort na de fractuur een sterk verhoogd risico hebben op een nieuwe fractuur. Vandaar dat secundaire fractuurpreventie snel moet worden gestart na een fractuur. Sven van Helden (Heelkunde) toonde onder andere aan dat 50 -plussers met een fractuur niet alleen een botprobleem hebben, maar nog meer frequent een probleem van vallen, en valpreventie is daarom belangrijk na een fractuur. Kirsten Huntjens (Heelkunde) kon door gebruik te maken van de gegevens uit MUMC+ en VieCuri MC aantonen dat 50-plussers met een recente fractuur minder kans hebben op nieuwe fracturen wanneer zij opgevangen, onderzocht en behandeld worden in een fractuurpoli, en na een fractuur langer overleven. 

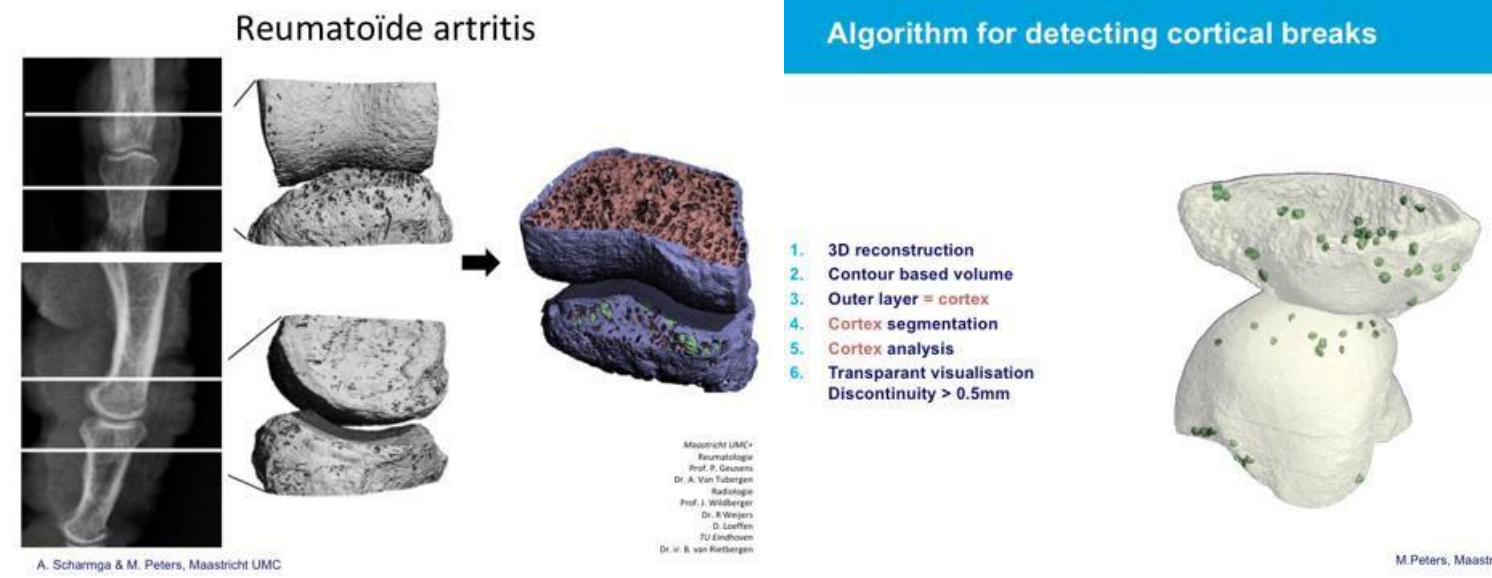

3D reconstruction Contour based volume Outer layer $=$ cortex Cortex segmentation Cortex analysis Transparant visualisation Transparant visualisation
Discontinuity $>0.5 \mathrm{~mm}$

Sandrine Bours, (Reumatologie), die binnenkort haar promotieonderzoek hoopt af te ronden toonde in VieCuri MC aan dat 60\% van patiënten met een recente fractuur een vitamine $D$ deficiëntie heeft en $70 \%$ onvoldoende calcium via de voeding inneemt. Daarnaast bleek $25 \%$ een al bekende metabole aandoening te hebben en bij nog eens $25 \%$ kon door middel van eenmalig bloedonderzoek een tot dan toe onbekende metabole aandoening wordt ontdekt die de kwaliteit van het botweefsel verslechterd. Deze bevindingen hebben bijgedragen aan de inzichten en ontwikkeling van de $3^{\text {de }}$ herziene Osteoporose en Fractuurpreventie richtlijn (2011) en de NHG standaard fractuurpreventie (2012) waar de nadruk niet meer zozeer op het ontdekken en behandelen van osteoporose ligt maar vooral wordt beschreven hoe fracturen kunnen worden voorkomen.

Het is onze doelstelling om binnen MUMC+ osteoporose, metabole botaandoeningen, fractuurrisico en mortaliteit verder te bestuderen. In dit kader is een samenwerking tot stand gebracht met het Garvan Institute (Sydney, Australië), om deze aspecten in grote internationale cohorten (uit Australië, Verenigd Koninkrijk, Schotland, Canada, Noorwegen, Zweden, Italië en de VS) nader te bestuderen.

De eerste resultaten van dit ambitieuze samenwerkingstraject, die zeer binnenkort worden gepresenteerd op het wereldcongres in de VS (ASBMR), zijn afkomstig uit Schotland waar onder supervisie van Prof. McLellan de eerste Fracture Liaison Service (FLS) werd gestart. Na 8 jaar follow-up blijkt dat patiënten die behandeld werden met botmedicatie (bisfosfonaten) via de FLS het risico op een nieuwe botbreuk $40 \%$ lager was en de sterfte $20 \%$ lager.

Bij 3/4 van de patiënten ouder dan 50 jaar die met een fractuur op de SEH komen gaat een val vooraf aan de fractuur. In het promotieonderzoek van Martha Caers werd vastgesteld dat 1/3 van alle patiënten een valincident heeft in het eerste jaar na een breuk en $45 \%$ in de eerste twee jaar na een breuk. Aanvullend stelde Kirsten Huntjens in haar promotieonderzoek vast dat de patiënten die zowel bot- als valrisicofactoren hadden het hoogste risico op een nieuwe factuur hebben. Uiteindelijk zijn we ter preventie van fracturen dus vooral op zoek naar een voorspelling van degene die gaat vallen en daarbij een fractuur oploopt (dat is bij ongeveer $10 \%$ van de vallers). Lisanne Vranken, als promovendus werkzaam in VieCuri MC, coördineert momenteel een prospectief onderzoek bij personen met een recente fractuur waarbij naast de analyse met DEXA, HR-pQCT en metabole botaandoeningen ook vitgebreid gekeken wordt naar bewegingsanalyses in samenwerking met de vakgroep Bewegingswetenschappen en binnen het Specialty Beweging in MUMC met als doel predictiemodellen te ontwikkelen voor valincidenten en daaraan gerelateerde fracturen en mortaliteit. 

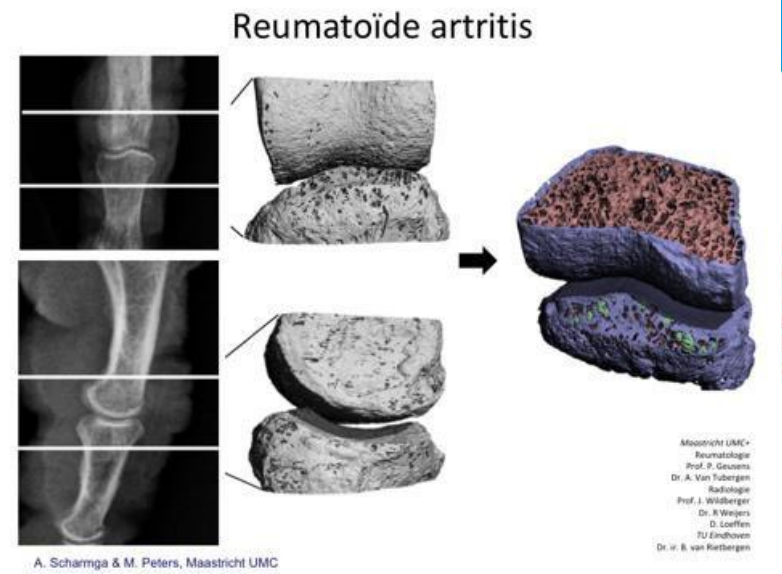

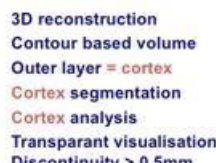

\section{De praktijk in Nederland}

Het zal u duidelijk zijn dat in de praktijk zowel de huisartsen als diverse specialismen te maken krijgen met fracturen, osteoporose en metabole aandoeningen. Het is daarom niet onlogisch dat internisten, reumatologen, geriaters, chirurgen en orthopeden een declaratiecode hebben voor de diagnose osteoporose. Ook huisartsen organisaties besteden aandacht aan deze problematiek. We hebben goede richtlijnen waarin systematische evaluatie en behandeling van patiënten met een hoog fractuurrisico sterk wordt aanbevolen. Teneinde de zorg rondom patiënte met een recente fractuur in kaart te brengen heeft promovendus Peter van den Berg (Reinier de Graaf, Delft) dit jaar een geanonimiseerd onderzoek in de Nederlandse niet-academische ziekenhuizen gedaan. Van de 90 ziekenhuizen reageerden er $24(27 \%)$. In de best presterende ziekenhuizen / regio's in Nederland werd bij niet meer dan 50\% van de patiënten met een fractuur systematisch onderzocht of zij osteoporose of andere onderliggende aandoeningen hebben en of medicamenteuze behandeling noodzakelijk is. Bij de patiënten die wel aanvullend geanalyseerd werden, werden metabole aandoeningen bij vrijwel iedereen onderzocht, $80 \%$ kreeg een DEXA onderzoek, en $60 \%$ een valrisicoanalyse. Bij $10 \%$ werden testen verricht in het kader van mobiliteit en spierfunctie. Het is daarnaast al langer bekend dat ongeveer de helft van de patiënten die behandeld wordt met anti-osteoporose medicatie binnen een jaar stopt met deze medicatie.

Het organiseren en in stand houden van goede zorg rondom patiënten met een recente fractuur vergt evenwel optimale samenwerking met vele partners. De inspanningen, zowel organisatorisch en inhoudelijk, zijn voor $\mathbf{1}^{\mathrm{e}}$ en $2^{\mathrm{e}}$ lijns zorgverleners op dit vlak vatbaar voor verbetering. Het is mijn hoop dat we in deze tijd van budgettering, met een sturende rol van verzekeraars en management het netwerk van partners in en buiten het MUMC+ met onze gegevens kunnen blijven overtuigen van het belang van deze zorg en dat we het vraagteken uit de titel van deze rede: "bot en kwaliteit: zijn we samen sterker?!" kunnen schrappen. 
Tot slot een woord van dank aan degenen die het mogelijk hebben gemaakt dat ik hier vandaag kan en mag staan.

In het bijzonder wil ik noemen de leden van het college van Bestuur, het college van Toezicht en de Raden van Bestuur MUMC+ en VieCuri MC voor de steun bij het uitbouwen van het onderzoek en het in mij gestelde vertrouwen.

De overleden mentoren Prof. Rik Huiskes, Prof. Ton Smals, Dr. Jos Mattousch en Dr. Harry Pennings. Het doet mij bijzonder deugd dat Mevr. Pennings en Mevr. Mattousch hierbij aanwezig kunnen zijn.

Prof. Dr. Ad.Hermus, mijn opleider endocrinologie en promotor. Dank voor de kennis en mogelijkheden die je me hebt gegeven voor het doen van onderzoek in metabole/endocriene ziekten en biomechanica.

De vakgroep Internisten en tot 2014 de maatschap internisten en MDL-artsen in VieCuri MC, voor het faciliteren van mijn activiteiten in MUMC. We hebben gezamenlijk een in onze poliklinische praktijk geïntegreerd onderzoeksklimaat en een Expertisecentrum voor Metabole Botaandoeningen kunnen ontwikkelen. Veel dank daarvoor!

Prof. Dr. A. Schols, die me de mogelijkheid heeft geboden om binnen NUTRIM een start te maken en mij in contact bracht met mensen uit vele verschillende disciplines waardoor het mogelijk werd vele ideeën te realiseren.

Prof. Dr. C. Stehouwer die me de mogelijkheid heeft geboden om zowel binnen De Maastricht Studie als binnen de Interne Geneeskunde / Reumatologie aan te kunnen sluiten waardoor fantastische mogelijkheden voor onderzoek en samenwerking ontstonden. De overige directieleden en medewerkers van De Maastricht Studie die allen hun uiterste best hebben gedaan om de XtremeCT in het gebouw geplaatst te krijgen en operationeel te krijgen.

De vakgroep reumatologie in het MUMC, in eerste instantie onder leiding van Prof van der Linden, en recentelijk van Prof. A. Boonen en Dr. Debbie Vossen. Dank voor de steun en het ruimhartig opnemen van een Endocrinoloog in een Reumatologisch team.

Prof. Dr. P. Geusens, wiens ervaring, netwerk en kennis aan de basis stonden van de fractuurpolikliniek in MUMC. Gezamenlijk hebben we de onderzoekslijnen kunnen ontwikkelen en ik hoop dat onze uitwisseling nog lang voortduurt.

Bert van Rietbergen, bescheiden maar als expert in biomechanica van bot een onmisbare schakel in vrijwel al onze onderzoekslijnen.

De promovendi en post-doc onderzoekers Tom Melai, Tineke van Geel en Caroline Wyers.

De medewerkers van de secretariaten Reumatologie in MUMC+, van NUTRIM en Interne Geneeslunde in VieCuri MC, voor de dagelijkse ondersteuning en de flexibiliteit die nodig is voor het werken op verschillende locaties.

Het "osteoteam" in VieCuri MC waarmee we sinds 2007 de patiëntenzorg en het onderzoek steeds verder uitbouwen.

De bedrijven en instanties die financiering van de onderzoeksprojecten mogelijk maken, in het bijzonder het bestuur van Stichting de Weijerhorst, hier vandaag aanwezig.

Mijn schoonouders, onbewust stonden jullie mede aan het fundament van mijn onderzoeksaspiraties omdat in de werkplaats bij jullie thuis de botblokjes voor de microCT metingen gezaagd werden.

Mijn ouders, ik ben er ongelooflijk trots op dat jullie mijn ouders zijn. Jullie hebben altijd voor mij, en ons gezin klaargestaan en hebben ervoor gezorgd dat ik me heb kunnen ontwikkelen tot wie we ik nu ben.

En als laatste ons gezin met onze twee kinderen Freek en Pleun. Fantastisch om te zien hoe jullie je ontwikkelen, ieder op geheel eigen wijze. Jullie zijn de zonnetjes in ons leven. Lieve Rianne, mijn rots in de branding en onmisbaar. Een ding staat vast: wij zijn samen sterker!

Ik heb gezegd. 